\title{
REVIEW
}

\section{Congenital hypothyroidism and thyroid cancer}

\author{
Gustavo Penna 1,2, Ileana G S Rubio3,4,5, Ester Saraiva Brust3,4, Juliana Cazarin6, Fabio Hecht6, \\ Nina Ramalho Alkmim²,7, Kamilla M A Brandão Rajão2,8 and Helton Estrela Ramos9,10,11 \\ 1Department of Clinical Medicine, Federal University of Minas Gerais, Belo Horizonte, Minas Gerais, Brazil \\ 2Endocrinology Service of Institute Orizonti, Belo Horizonte, Minas Gerais, Brazil \\ 3Department of Biological Science, Molecular Thyroid Science Laboratory, Federal University of São Paulo, São Paulo, Brazil \\ 4Biotechnology Post-graduation Program, Federal University of São Paulo, São Paulo, Brazil \\ ${ }^{5}$ Estructural and Functional Biology Program, Federal University of São Paulo, São Paulo, Brazil \\ ${ }^{6}$ Laboratory of Endocrine Physiology, Institute of Biophysics Carlos Chagas Filho, Federal University of Rio de Janeiro, Rio de Janeiro, Brazil \\ 7Post-Graduation Program Molecular Medicine, Faculty of Medicine, Federal University of Minas Gerais, Belo Horizonte, Brazil \\ ${ }^{8}$ Endocrinology Service of Hospital das Clínicas, Federal University of Minas Gerais, Belo Horizonte, Brazil \\ ${ }^{9}$ Department of Bioregulation, Health \& Science Institute, Thyroid Study Laboratory, Federal University of Bahia, Salvador, Brazil \\ 10Post-Graduation Program Medicine and Health, Faculty of Medical Sciences, Federal University of Bahia, Salvador, Bahia, Brazil \\ ${ }_{11}$ Post-Graduate Program in Interactive Processes of Organs and Systems, Health \& Science Institute, Federal University of Bahia, Salvador, Bahia, Brazil
}

Correspondence should be addressed to G Penna: gustavocpenna@gmail.com

\begin{abstract}
Differentiated thyroid carcinoma (DTC) combined with congenital hypothyroidism $(\mathrm{CH})$ is a rare situation, and there is no well-established causal relationship. $\mathrm{CH}$ is a common congenital endocrine, while DTC occurring in childhood represents $0.4-3 \%$ of all malignancies at this stage of life. The association of $\mathrm{CH}$ with DTC could be related to dyshormonogenetic goiter (DHG) or developmental abnormalities. This review will explore the clinical features and the molecular mechanisms potentially associated with the appearance of DTC in $\mathrm{CH}$ : sporadic somatic driver mutations, chronic increase of thyroid-stimulating hormone (TSH) levels, higher concentrations of hydrogen peroxide $\left(\mathrm{H}_{2} \mathrm{O}_{2}\right)$, cell division cycle associated 8 (Borelain/CDC8) gene mutations, and in others genes associated with $\mathrm{CH}$ - either alone or associated with the mechanisms involved in dyshormonogenesis. There are some pitfalls in the diagnosis of thyroid cancer in patients with $\mathrm{CH}$ with nodular goiter, as the proper cytological diagnosis of nodules of patients with dyshormonogenesis might be demanding due to the specific architectural and cytological appearance, which may lead to an erroneous interpretation of malignancy. The purpose of this article is to suggest an analytical framework that embraces the fundamental relationships between the various aspects of $\mathrm{CH}$ and CDT. In face of this scenario, the entire genetic and epigenetic context, the complex functioning, and cross talk of cell signaling may determine cellular mechanisms promoting both the maintenance of the differentiated state of the thyroid follicular cell and the disruption of its homeostasis leading to cancer. Whereas, the exact mechanisms for thyroid cancer development in $\mathrm{CH}$ remain to be elucidated.
\end{abstract}
Key Words
- congenital hypothyroidism
- goiter
- dyshormonogenesis
- thyroid cancer

https://erc bioscientifica.com https://doi.org/10.1530/ERC-21-0159
C) 2021 Society for Endocrinology Published by Bioscientifica Ltd. Printed in Great Britain
Endocrine-Related Cancer (2021) 28, R217-R230 


\section{Introduction}

Differentiated thyroid carcinoma (DTC) is a common malignancy within the endocrine system but a rare disease in children, accounting for up to $3 \%$ of cases in all childhood cancers, and with an annual incidence of 0.2-1 cases per million children (Paulson et al. 2019). The vast majority (>90\%) of follicular-derived thyroid carcinomas is papillary thyroid carcinoma (PTC) (Nilsson \& Fagman 2017). It has been previously shown that pediatric patients with a history of goiter or benign thyroid nodule are at increased risk of presenting DTC (Gupta et al. 2013). However, a potential study bias is that children with known congenital diseases including hypothyroidism are more strictly followed with serial thyroid ultrasound during life, leading to the early discovery of incidental PTCs.

The possibility of a causal association instead of a direct cause-effect link in cases of co-occurrence of congenital hypothyroidism and thyroid cancer should also be considered. Nevertheless, traditional risk factors well recognized in the development of DTC in children include iodine deficiency, autoimmune thyroid disease, and radiation exposure (Rose et al. 2012, Francis et al. 2015, Turcotte et al. 2017, Paulson et al. 2019, Pessôa-Pereira et al . 2019, Zirilli et al. 2019). Yet, it is true that Hashimoto's thyroiditis could partially justify the association between higher serum thyroid-stimulating hormone (TSH) levels and an increased hazard of malignancy (Boelaert 2009). Undeniably, DTC has been further reported continuously in patients with congenital goiter (CG) or dyshormonogenesis (DH), conjecturing that the uninterrupted TSH stimulus may perhaps contribute to the propensity of DTC; however, in reality, this association has been advised by some authors (Boelaert 2009, Fiore et al. 2010) and not recommended by others (Castro et al. 2011, Kim et al. 2011).

Thyroid dysgenesis (TD) is the foremost source of congenital hypothyroidism $(\mathrm{CH})$, and it comprises several distinct phenotypes: (a) athyreosis, the most severe, in which no thyroid vestige can be found; (b) ectopic, frequently a primitive gland present outside the thyroid bed; (c) hypoplasia, considered a minuscule orthotopic gland and d) hemiagenesis, identified by the absence of one lobe, mostly meaning an ulterior evolution error (Ramos et al. 2008, Cerqueira et al. 2018).

However, $\mathrm{DH}$ is the least frequent type of $\mathrm{CH}$, representing 10 to $15 \%$ of all CH cases (Grasberger \& Refetoff 2011). DH is caused by altered proteins involved in one of the crucial steps of thyroid hormone (TH) biosynthesis and secretion: (a) solute carrier family 5 member 5 (SLC5A5/NIS): iodide trapping from blood; (b) solute carrier family 26 member 4 (pendrin): iodide discharge beyond the apical membrane; (c) thyroid peroxidase (TPO), dual oxidase 2 (DUOX2) and dual oxidase maturation factor 2 (DUOXA2): organification of iodide within the follicular lumen; (d) thyroglobulin (TG): a substrate for TH production and e) iodotyrosine deiodinase (DEHAL1): the ability to recycle iodine (Grasberger \& Refetoff 2011).

When associated with a congenital thyroid problem, pediatric DTC carries some unique dilemmas, both at the diagnostic and therapeutic levels, which need to be appropriately addressed to assure the best management and result. The purpose of this article is to suggest an analytical framework that embraces the primary relationships between the various aspects of congenital hypothyroidism and thyroid cancer. This review will explore the mechanisms involved in $\mathrm{DH}$ or $\mathrm{TD}$, either alone or associated with the molecular features potentially associated with the appearance of $\mathrm{CDT}$ in $\mathrm{CH}$ - one or more of them: sporadic somatic driver mutations (constitutive activation of mitogen-activated protein kinase (MAPK), phosphatidylinositol-4,5-bisphosphate 3-kinase catalytic subunit alpha (PI3K)/AKR mice thymoma oncogene (AKT) activation), the chronic increase of TSH levels, higher concentrations hydrogen peroxide $\left(\mathrm{H}_{2} \mathrm{O}_{2}\right)$, cell division cycle associated 8 (Borelain/CDC8) gene mutations and others genes associated with $\mathrm{CH}$.

\section{Clinical aspects of thyroid cancer in sporadic forms of congenital hypothyroidism}

\section{Thyroid dysgenesis (TD)}

Ectopic thyroid (ET) occurs when it is not located in the standard thyroid compartment, generally observed in the lingual/sublingual (in most cases), thyroglossal, laryngotracheal or lateral cervical areas (KluboGwiezdzinska et al. 2011, Nilsson \& Fagman 2017). It might be associated with an involution in size and hypofunction sometimes appearing in the neonatal period or later (puberty or adult life) (Ramos et al. 2008). Despite the ability of the ectopic thyroid to synthesize T4, it may be insufficient at some point in life leading to hypothyroidism and goiter, as observed in some of the patients (Camargo 2018). ET may be subjected to the same pathological processes as the normal orthotopic thyroid, such as autoimmune disease, hyperplasia, and tumorigenesis, albeit, it has
(C) 2021 Society for Endocrinology Published by Bioscientifica Ltd. Printed in Great Britain 
not been considered an increased risk condition for malignant transformation (Klubo-Gwiezdzinska et al. 2011, Tian et al. 2014). The association between lingual thyroid and DTC was recently reviewed (Klubo-Gwiezdzinska et al. 2011, Huang et al. 2019). To our knowledge, the majority of DTC cases associated with ET are not related to a previous history of $\mathrm{CH}$; although, in some cases, hypothyroidism has been observed or has become symptomatic during puberty, pregnancy, or menses (Diaz-Arias et al. 1992, Pérez et al. 2003, Kennedy \& Riefkohl 2007, Sevinç et al. 2010, Chen et al. 2013, Mogi et al. 2018). Yet, in relation to the thyroglossal duct associated with DTC, to the best of our knowledge, most cases are not linked to a previous history of $\mathrm{CH}$. Siklar et al. described a patient who presented $\mathrm{CH}$ detected in the neonatal period and who, subsequently, developed synchronous thyroglossal cyst carcinoma and DTC at 19 years old (Şıklar et al. 2012).

Hemiagenesis (HG) is an uncommon congenital abnormality in which a thyroid lobe fails to develop (Ramos et al. 2008). The real prevalence of HG is unknown because it is typically detected incidentally in imaging obtained to assess other conditions, and a compensatory mechanism of thyroid hyperplasia with goiter formation might occur to balance the hormonal deficit. An unilateral goiter in the remnant lobe is commonly confounded with a thyroid nodule or mass (Castanet et al. 2005, Wu et al. 2012). The coexistence of HG and DTC has been reported in euthyroid adults (not in children with $\mathrm{CH}$ ), and this condition was not consistently linked to an increased risk of tumorigenesis (McHenry et al. 1995, Huang et al. 2002, Pizzini et al. 2005, Niedziela 2006, Wang et al. 2014). The incidence of co-occurrence of DTC and HG has been estimated at 3\%, but this does not seem to justify empirical thyroidectomy or active surveillance (Mikosch et al. 1999, Maiorana et al. 2003, Wu et al. 2010, 2012).

\section{Dyshormonogenesis (DH)}

$\mathrm{DH}$ is a rare disorder, with a worldwide incidence of $1: 30,000$ to $1: 50,000$ newborns, and it is often combined with goiter formation, sometimes occurring since the intrauterine period (CG, congenital goiter) (Ghossein et al. 1997, Rastogi \& LaFranchi 2010). Commonly, the goiter is first diffused and gradually becomes nodular, with solid and fleshy consistency, essentially identified in patients from a non-endemic area. As previously mentioned, the increase in thyroid volume can also be observed at birth, without the maternal intake of goitrogenic substances
(Deshpande \& Bobhate 2005), or during fetal development (Huel et al. 2009).

In turn, DH can be subcategorized based on radioiodine uptake and perchlorate test in (a) iodide transport defect (ITD) (Nicola et al. 2011), who has little or no uptake of radioiodine in the thyroid and (b) iodide organification defect (IOD) with normal radioiodine uptake (Nascimento et al. 2003). The patient's phenotype depends on the severity of the inborn TH biosynthesis error. A severe defect will lead to neonatal $\mathrm{CH}$, goiter, and developmental retardation if not properly treated (Grasberger \& Refetoff 2011). Veritably, DH is present only in a minority of $\mathrm{DH}$ patients shortly after birth, and it is mainly attributed to relevant biallelic mutations in the TPO, NIS, TG, or pendrin (PDS) genes (Rubio \& Medeiros-Neto 2009, Ris-Stalpers \& Bikker 2010, Spitzweg \& Morris 2010, Grasberger \& Refetoff 2011, Wémeau \& Kopp 2017). In contrast, weaker defects, typically attributed to DUOX2 gene mutations, might be present during adolescence or pregnancy as a minimal thyroid hypofunction (Grasberger \& Refetoff 2011, Muzza \& Fugazzola 2017).

Although rare, follicular carcinoma, papillary thyroid carcinoma, or microcarcinoma have been reported in the setting of DH (Table 1). Moreover, follicular thyroid carcinoma (FTC) has been reported more than other types (Potter \& Morris 1935, McGirr et al. 1959, Stanbury \& Vickery 1962, Medeiros-Neto \& Oliveira 1970, Illum 1978, Cooper et al. 1981, Abs et al. 1991, Medeiros-Neto et al. 1998, Ozlük et al. 1998, Camargo et al. 2001, Bashir et al. 2004, Kim et al. 2004, Alzahrani et al. 2006, Chertok Shacham et al. 2012). In fact, in the last few years, after improvements in the anatomopathological examination, the association between dyshormonogenic goiter (DHG) and DTC has been increasing, as described by Ghoseein et al., who observed a prevalence as high as 6\% (Ghossein et al. 1997). Long-term follow-up and regular neck ultrasound imaging are being considered to prevent the late diagnosis of DTC in patients with DHG (Boelaert 2009), and the recent European consensus guidelines update recommends a periodical neck ultrasound every 2 to 3 years in children and adolescents with goitrous $\mathrm{CH}$ due to DHG, to identify nodules that may require fineneedle aspiration biopsy to rule out thyroid carcinoma (van Trotsenburg et al. 2021). In reality, most genetic defects in all known thyroid-specific factors required for the synthesis of thyroid hormones have been described in association with DTC (Table 1). (c) 2021 Society for Endocrinology Published by Bioscientifica Ltd. Printed in Great Britain 
Table 1 Cases of thyroid malignancy associated with dyshormonogenetic goiter and congenital hypothyroidism due to thyroid dysgenesis.

\begin{tabular}{|c|c|}
\hline $\begin{array}{l}\text { Reference } \\
\text { ( } n \text {, number of cases) }\end{array}$ & $\begin{array}{l}\text { Sex }(F / M) \text { and } \\
\text { age (years) at } \\
\text { surgery }\end{array}$ \\
\hline $\begin{array}{l}\text { Potter \& Morris } \\
1935(n=5)\end{array}$ & $\begin{array}{l}3 \mathrm{~F}, 2 \mathrm{M} \\
(14-19)\end{array}$ \\
\hline $\begin{array}{l}\text { McHenry et al. } \\
1995(n=1)\end{array}$ & $\begin{array}{l}1 \mathrm{~F} \text { (age not } \\
\text { reported) }\end{array}$ \\
\hline
\end{tabular}

Rickles $1947(n=2) \quad 2 \mathrm{~F}(10,11)$

$$
\begin{array}{lr}
\text { Thieme } 1957 & 1 \mathrm{M}, 1 \mathrm{~F} \\
(n=2) & (24,22)
\end{array}
$$

\begin{tabular}{|c|c|}
\hline $\begin{array}{l}\text { Roberts } 1957 \\
(n=1)\end{array}$ & $1 \mathrm{M}(9)$ \\
\hline $\begin{array}{l}\text { McGirr et al. } 1959 \\
\quad(n=1)\end{array}$ & $1 F(9)$ \\
\hline $\begin{array}{c}\text { Stanbury \& Vickery } \\
1962(n=1)\end{array}$ & $1 \mathrm{M}(27)$ \\
\hline $\begin{array}{l}\text { Crooks et al. } 1963 \\
(n=1)\end{array}$ & $1 \mathrm{M}(16)$ \\
\hline $\begin{array}{l}\text { Medeiros-Neto \& } \\
\text { Oliveira 1970) } \\
(n=1)\end{array}$ & $1 F(27)$ \\
\hline $\begin{array}{l}\text { Hayek et al. } 1973 \\
(n=1)\end{array}$ & $1 \mathrm{M}(7)$ \\
\hline Illum $1978(n=1)$ & $1 F(38)$ \\
\hline $\begin{array}{l}\text { Cooper et al. } 1981 \\
(n=2)\end{array}$ & $\begin{array}{l}1 \mathrm{M}, 1 \mathrm{~F} \\
(29,23)\end{array}$ \\
\hline
\end{tabular}

Yashiro et al. $1987 \quad 1 \mathrm{M}(35)$ $(n=1)$

Abs et al. 1991 $(n=1)$

Ghossein et al. $1997(n=3)$

$1 \mathrm{~F}(8)$

Clinical, macroscopic and
microscopic aspects

Goiter, encapsulated neoplasm or infiltration of connective tissue, vascular invasion Unsuspected hemiagenesis, Graves's disease, marked hyperplasia of a single lobe, and isthmus

Case 1: multiple adenomas, no invasion;

Case 2: papillary adenocystoma

Cases 1 and 2: deafness, MNG; Case 1: vascular emboli, capsular invasion

Deafness, MNG

MNG (100 g)

MNG, vascular invasion

MNG (90 g), vascular invasion

MNG, capsular, and vascular invasion

MNG, trabeculae, and ribbons of irregular cells with large nuclei having coarse chromatin and frequent mitoses, vascular invasion

Adenomatous colloid goiter (initially), capsular, vascular and ETE with muscular invasion

Case 1 (M): MNG, ETE (trachea and soft tissue), no vascular invasion;

Case 2 (F): MNG (90 g), intermediate undifferentiation, no vascular invasion

MNG (108 g), vascular invasion

Deafness, toxic MNG, ETE

$2 \mathrm{M}(33,9)$

$0.7 \mathrm{~cm}$;

\begin{tabular}{l} 
Histology (reported in \\
the original publication) \\
\hline Adenocarcinoma
\end{tabular}

Case 1: carcinoma

(subtype not

reported);

Case 2: papillary

adenocystoma of

low-grade

malignancy

Case 1: adenomatous

goiter with

carcinomatous

change;

Case 2: medullary

clear-cell

adenocarcinoma

Consistent with

adenocarcinoma

Adenocarcinoma

No

Distant

metastasis

No

Molecular defect (mutation)

No

No

No

FTC

Hyperplasia with adenocarcinoma change

FTC

No

Suspected carcinoma No

Suspected TG defect (no molecular study)

FTC

No

FTC

Case 1: right defect (no molecular study)

scapula

Case 2:

posterior ilium and lung

PTC

No

No

FTC

Case 1 ( $M, 33$ years): MNG (26 g), MPTC

Case 2 ( $F$, 8 years): $M N G, 0.5 \mathrm{~cm}$; Case 3 (M, 9 years): MNG (18 g), multifocal $(0.8$ and $0.5 \mathrm{~cm}$ ) 
Table 1 Continued.

\begin{tabular}{|c|c|}
\hline $\begin{array}{l}\text { Reference } \\
\text { ( } n, \text { number of cases) }\end{array}$ & $\begin{array}{l}\text { Sex }(F / M) \text { and } \\
\text { age (years) at } \\
\text { surgery }\end{array}$ \\
\hline $\begin{array}{l}\text { Medeiros-Neto } \\
\text { et al. } 1998(n=1)\end{array}$ & $\begin{array}{c}1 \mathrm{~F} \text { (7 days } \\
\text { of age) }\end{array}$ \\
\hline $\begin{array}{l}\text { Ozlük et al. } 1998 \\
(n=1)\end{array}$ & $1 F(49)$ \\
\hline $\begin{array}{c}\text { Camargo et al. } \\
2001(n=1)\end{array}$ & $1 F(53)$ \\
\hline $\begin{array}{l}\text { Bashir et al. } 2004 \\
\quad(n=1)\end{array}$ & $1 \mathrm{~F}$ \\
\hline $\begin{array}{l}\text { Kim et al. } 2004 \\
(n=1)\end{array}$ & $1 \mathrm{M}$ \\
\hline $\begin{array}{l}\text { Pizzini et al. } 2005 \\
\quad(n=1)\end{array}$ & $1 \mathrm{M}(54)$ \\
\hline $\begin{array}{l}\text { Hishinuma et al. } \\
2005(n=7)\end{array}$ & $\begin{array}{c}6 \mathrm{~F}(12,17, \\
27,28, \\
36,38) \\
1 \mathrm{M}(35)\end{array}$ \\
\hline $\begin{array}{c}\text { Alzahrani et al. } \\
2006(n=1)\end{array}$ & $1 \mathrm{M}(21)$ \\
\hline $\begin{array}{l}\text { Drut \& Moreno } \\
2009(n=1)\end{array}$ & $1 F(5)$ \\
\hline $\begin{array}{l}\text { Kallel et al. } 2009 \\
\quad(n=1)\end{array}$ & $1 \mathrm{M}(13)$ \\
\hline $\begin{array}{l}\text { Oguz et al. } 2009 \\
(n=1)\end{array}$ & $1 \mathrm{M}(19)$ \\
\hline $\begin{array}{l}\text { Raef et al. } 2010 \\
\quad(n=1)\end{array}$ & $1 F(31)$ \\
\hline $\begin{array}{l}\text { Chertok Shacham } \\
\text { et al. } 2012(n=1)\end{array}$ & $1 \mathrm{M}$ \\
\hline $\begin{array}{l}\text { Wu et al. } 2012 \\
\quad(n=7)\end{array}$ & $\begin{array}{l}7 \text { (age and } \\
\text { sex not } \\
\text { reported) }\end{array}$ \\
\hline $\begin{array}{l}\text { Sakurai et al. } 2013 \\
\quad(n=1)\end{array}$ & $1 \mathrm{M}(37)$ \\
\hline $\begin{array}{l}\text { Erden et al. } 2013 \\
\quad(n=1)\end{array}$ & $1 F(17)$ \\
\hline $\begin{array}{l}\text { Zhu et al. } 2015 \\
\qquad(n=1)\end{array}$ & $1 \mathrm{~F}$ \\
\hline
\end{tabular}

\begin{tabular}{l} 
Clinical, macroscopic and \\
microscopic aspects \\
\hline Solid cervical mass ( $74 \mathrm{~g}$ ) with \\
calcifications and ETE to the \\
base of the tongue and \\
hypopharynx, mediastinum and \\
vascular invasion
\end{tabular}

Deafness, large goiter, capsular invasion, no vascular invasion, associated with breast invasive ductal carcinoma

Deafness, goiter (150 g), ETE, death by hemoptysis caused by tumor invasion

MNG

Deafness, large goiter

Hemiagenesis of left thyroid lobe, with multinodular lesions in the right lobe, mediastinal extension, dysphagia

Goiter, BRAFV600E and BRAFK600E somatic mutations in tumors from two patients

MNG, RAS mutation negative

MNG, malignant nodule with 0.7 cm, PTC at FNA cytology (nuclear changes, pseudoinclusions), vascular invasion, LN metastasis

Compressive MNG, multifocal PTC (dominant lesion, $0.6 \mathrm{~cm}$ ), microfollicular pattern, limph node metastatis $(0.3 \mathrm{~cm})$

Deafness, MNG, no capsular or vascular invasion

MNG, two surgeries for DTC (first: two foci of MFVPTC, 0.5 $\mathrm{cm})$, recurrence after 4 years of follow-up

MNG with tracheal compression, no vascular invasion

Hemiagenesis

Deafness, MNG (482 g), encapsulated follicular lesion, no vascular or LN invasion; twin brother with PDS mutation but benign MNG at surgery

Recurrence of MNG 6 years after first operation

Multifocal PTC, lymph node, and nerve invasion

\begin{tabular}{l} 
Histology (reported in \\
the original publication) \\
\hline FTC
\end{tabular}

FTC No

FTC with areas of Lung

metastasis

Molecular defect

Lung and bone (both femurs, (mutation) right tibia)

TPO (c.1-bp ins., 2505C)

anaplastic transformation

FTC

UN

Suspect of PDS

defect (no

Poorly UN molecular study)

differentiated FTC

PTC

No

PDS

Suspect of PDS defect (no molecular study)

DS (c.279delT)

\section{PTC}

No

TG (p.C1077R)

1 FTC

(p.C1264R)

(p.C1996S)

(p.G2375R)

FTC

PTC

Skull, abdomen, TG (g.IVS5+1G>A) femur (Stop codon)

$$
\text { No No }
$$

MFVPTC

No

No

PTC

No

PDS

PTC with follicular and oncocytic variants
Skull, pelvis and TG (c.6725G>A; lung p.R2223H)

$\begin{array}{lll}\text { FTC } & \text { No } & \text { TPO (c.875C }>\text { T) } \\ \text { PTC }(n=5) & \text { No } & \text { No } 292 F)\end{array}$

$\mathrm{FTC}(n=1)$

Mixed PTC/FTC $(n=1)$

FVPTC No

PDS (c.2168A>G; c.ins2110GCTGG)

\begin{tabular}{lll} 
PTC & Lung & No \\
PTC & No & TPO (c.2268-2269 \\
& & insT) \\
\hline
\end{tabular}


Table 1 Continued.

\begin{tabular}{|c|c|}
\hline $\begin{array}{l}\text { Reference } \\
\text { ( } n, \text { number of cases) }\end{array}$ & $\begin{array}{l}\text { Sex }(F / M) \text { and } \\
\text { age (years) at } \\
\text { surgery }\end{array}$ \\
\hline $\begin{array}{l}\text { (Agretti et al. 2016) } \\
(n=1)\end{array}$ & $1 F(37)$ \\
\hline $\begin{array}{l}\text { (Tong et al. 2016) } \\
\quad(n=11)\end{array}$ & $\begin{array}{l}2 \mathrm{M}(23,34), \\
9 \mathrm{~F}(15,22, \\
34,37,41, \\
49,53, \\
54,64)\end{array}$ \\
\hline $\begin{array}{l}\text { (Yoon et al. 2020) } \\
\quad(n=1)\end{array}$ & $1 F(46)$ \\
\hline
\end{tabular}

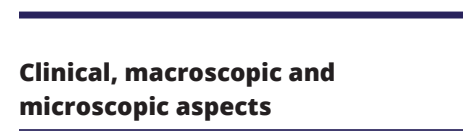

Recurrent MNG (two operations) malignancy at second operation (multifocal FVPTC, ETE: fibromuscular tissue infiltration)

Deafness, MNG, extensive fibrosis, hyperplastic nodule with papillary hyperplasia, solid growth pattern or insular/ trabecular growth

Large heterogeneous and hypoechoic nodule with internal calcification $(6 \mathrm{~cm})$ in the right lobe, as well as dense calcification in the left lobe $(0.9 \mathrm{~cm})$

\begin{tabular}{|c|c|c|}
\hline $\begin{array}{l}\text { Histology (reported in } \\
\text { the original publication) }\end{array}$ & $\begin{array}{l}\text { Distant } \\
\text { metastasis }\end{array}$ & $\begin{array}{l}\text { Molecular defect } \\
\text { (mutation) }\end{array}$ \\
\hline FVPTC & No & $\begin{array}{l}\text { NIS } \\
\text { (c.970_1526del557; } \\
\text { Y324LfsX12) }\end{array}$ \\
\hline FVPTC & No & $\begin{array}{l}\text { PDS }(c .412 G>T) \\
\text { (c. } 1001+1 G>A)\end{array}$ \\
\hline ATC & $\begin{array}{l}\text { Lung, bone and } \\
\text { liver }\end{array}$ & $\begin{array}{l}\text { TG }(c .3790 T>C ; \\
\text { c. } 7070 T>C)\end{array}$ \\
\hline
\end{tabular}

\section{Molecular aspects of thyroid cancer associated with genetic forms of congenital hypothyroidism}

\section{Thyroid dysgenesis genetic defects}

NK2 homeobox 1 (NKX2-1) is a crucial transcription factor for thyroid development, and germline mutations have been hypothesized as susceptibility elements of DTC (Ngan et al. 2009). In a genome-wide association study, a common variant near the NKX2-1 gene was associated with DTC (Gudmunsson et al. 2009). In one study, a frequent lossof-function alteration of NKX2-1 (p.A339V) was associated with PTC in patients harboring multinodular goiter (MNG) (Ngan et al. 2009). However, no mutations in the NKX2-1 gene have been described in patients with $\mathrm{CH}$ associated with DTC, and other studies have not confirmed NKX2-1 mutations as a risk factor for DTC in the clinical context of MNG (Cantara et al. 2010). Currently, the available data do not support a role for NKX2-1 in the predisposition to hereditary thyroid malignancy; therefore, we do not advise screening $\mathrm{CH}$ patients with NKX2-1 mutation for DTC (Villani et al. 2017).

Loss-of-function mutations in the forkhead box E1 (FOXE1) gene, another essential transcription factor for the migration of primordial thyroid cells, have been reported in patients with Bamforth-Lazarus syndrome, characterized by $\mathrm{CH}$ with TD (normally athyreosis), cleft palate, spiky hair, choanal atresia, and bifid epiglottis (Ramos et al. 2008, Carré et al. 2014). Notably, Landa and colleagues identified a causal variant within the FOXE1 promoter that was associated with PTC susceptibility (Landa et al. 2009). Previously, other sequence variant (9q22.33) near FOXE1 locus was associated with increased predisposition to papillary and follicular thyroid cancer (Gudmunsson et al. 2009). However, cases of DTC have not been reported in patients with $\mathrm{CH}$ due to mutations in the FOXE1 gene (Fernández et al. 2015).

\section{Dyshormonogenesis genetic defects}

As already described, DHG is related to TPO, NIS, TG, pendrin, and DUOX2 gene mutations (Rubio \& Medeiros-Neto 2009, Ris-Stalpers \& Bikker 2010, Spitzweg \& Morris 2010, Grasberger \& Refetoff 2011, Muzza \& Fugazzola 2017, Wémeau $\&$ Kopp 2017). DTC cases in patients with TPO mutations were described (Medeiros-Neto et al. 1998, Chertok Shacham p.S292F) has also been described in 13 members of a Tunisian family; in which, only MNG with atypical oncocytic differentiation in two subjects has been reported (BougachaElleuch et al. 2015). Two single-nucleotide polymorphisms of TPO (SNP; rs2048722 and rs732609) were linked the with high-risk of DTC in two European populations (Cipollini et al. 2013). TG gene mutations were also reported (Hishinuma et al. 2005), including in association with an anaplastic thyroid cancer (Yoon 2020).

Homozygous deletion in the NIS protein associated with ITD was reported in a DTC patient who harbored a DHG with a late diagnosis, low adherence to $\mathrm{LT}_{4}$ treatment, and previous partial thyroidectomy (Agretti et al. 2016). et al. 2012, Zhu et al. 2015). One of these mutations (c.875C>T, (c) 2021 Society for Endocrinology Published by Bioscientifica Ltd. Printed in Great Britain 
Pendred syndrome (PS) is caused by biallelic mutations in the SLC26A4/PDS gene. Very few patients with PS have been diagnosed with DTC, mostly associated with iodine deficiency or sustained TSH elevations (Illum 1978, Abs et al. 1991, Ozlük et al. 1998, Camargo et al. 2001, Kim et al. 2004, Oguz et al. 2009, Sakurai et al. 2013). PS patients with MNG should be monitored regularly with sporadic ultrasound assessment and FNA in suspicious nodules (Wémeau \& Kopp 2017, van Trotsenburg et al. 2021).

DUOX2 gene biallelic loss-of-function mutation phenotype includes normally localized thyroid gland, presenting regular to extended size, associated with normal or high serum levels of TSH and TG (Pizzini et al. 2005, Niedziela 2006) but not associated with DTC. So far no germline mutations in the DUOX2 and DUOXA2 genes have been reported in DTC patients with DH (Carvalho \& Dupuy 2013, Ameziane-El-Hassani et al. 2016, Azouzi et al. 2017, Muzza \& Fugazzola 2017). A novel DUOX2 variant (DUOX $\left.2_{\mathrm{Y} 1203 \mathrm{H}}\right)$ was described as a gain-of-function mutation and could be investigated for being potentially implicated in redox upregulation related to DTC (Bann et al. 2019).

\section{Genomic insights of congenital hypothyroidism and differentiated thyroid carcinoma association}

Borealin/CDC8 gene mutations were associated to thyroid dysgenesis. Borealin is a major component of the chromosomal passenger complex (CPC) with functions in mitosis. The authors showed that the identified mutations decreased adhesion and migration (Carré et al. 2017). Thus, variants in this gene may participate in cellular mechanisms related to cancer. In a previous study, a list of genes described as candidate genes in congenital hypothyroidism containing an entire spectrum of possible causative defects of $\mathrm{CH}$ pathology was described (Camargo et al. 2018). When those 190 genes set was submitted to the enrichment analyses (Kuleshov et al. 2016), it generated a list including 16 pathways associated with cancer development or progression (Fig. 1), implying that genes associated with congenital hypothyroidism may also be involved in the pathology of thyroid cancer. Furthermore, when rare variants (frequency lower than $1 \%$ or without data in The 1000 Genomes Project population)

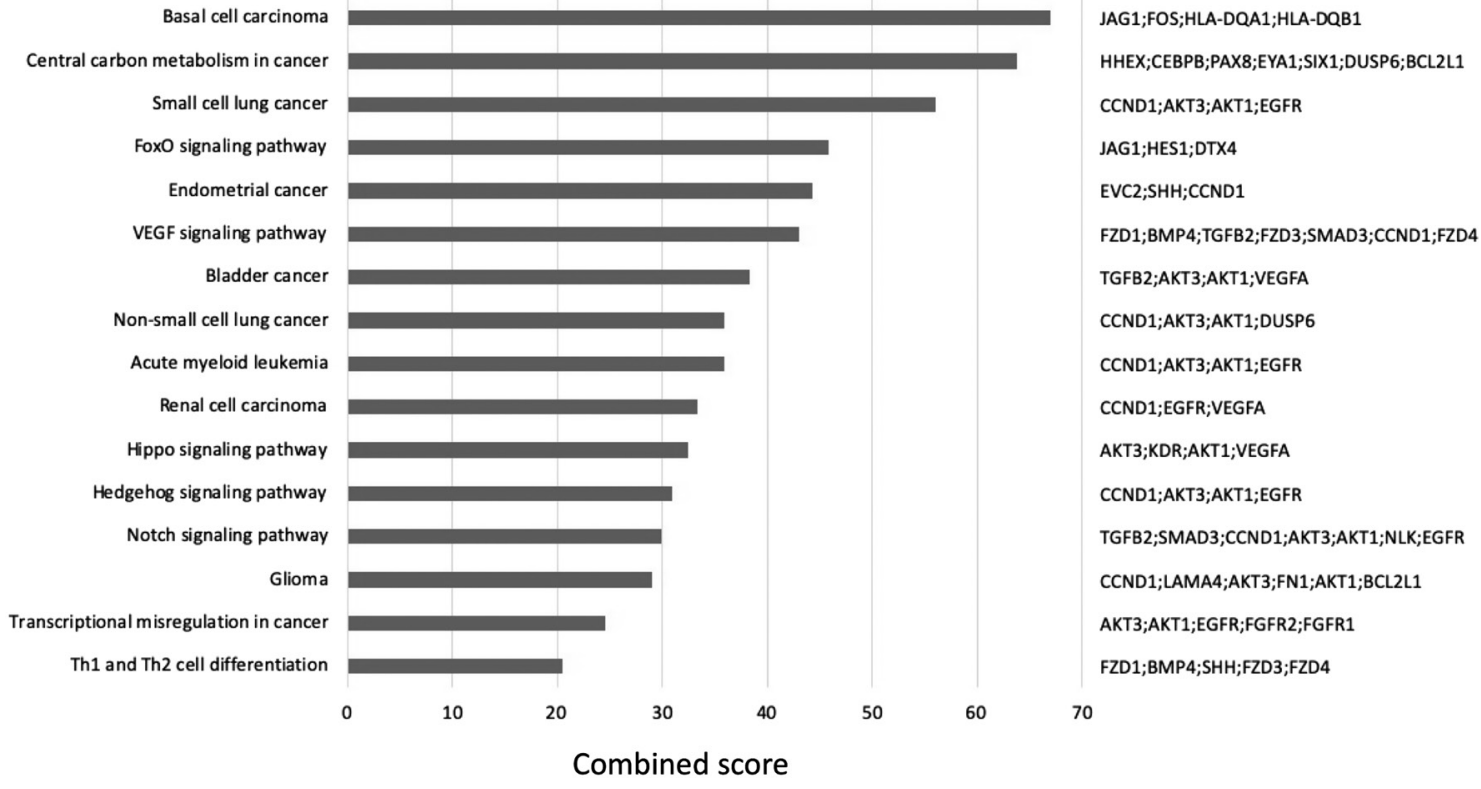

Figure 1

KEEG enrichment analysis of candidate genes in congenital hipothyroidism. Score bar plots and genes from the input that were found to be associated with each term ( $P$-value < 0.05) (Kuleshov et al. 2016). AKT1, AKT serine/threonine kinase 1; AKT3, AKT serine/threonine kinase 3; BCL2L1, BCL2 like 1; BMP4, bone morphogenetic protein 4; CCND1, cyclin D1; CEBPB, CCAAT enhancer binding protein beta; DTX4, deltex E3 ubiquitin ligase 4; DUSP6, dual specificity phosphatase 6; EVC2, EvC ciliary complex subunit 2; EYA1, EYA transcriptional coactivator and phosphatase 1; FGFR1, fibroblast growth factor receptor 1; FGFR2, fibroblast growth factor receptor 2; FN1, fibronectin 1; FOS, Fos proto-oncogene, AP-1 transcription factor subunit; FZD1, frizzled class receptor 1; FZD3, frizzled class receptor 3; FZD4, frizzled class receptor 4; HES1, Hes family BHLH transcription factor 1; HHEX, hematopoietically expressed homeobox; HLA-DQA1, major histocompatibility complex, class II, DQ alpha 1; HLA-DQB1, major histocompatibility complex, class II, DQ beta 1; JAG1, jagged canonical notch ligand 1; KDR, kinase insert domain receptor; LAMA4, laminin subunit alpha 4; NLK, Nemo like kinase; PAX8, paired box 8; SHH, sonic Hedgehog signaling molecule; SIX1, SIX homeobox 1; SMAD3, SMAD family member 3; TGFB2, transforming growth factor beta 2; VEGFA, vascular endothelial growth factor $\mathrm{A}$. 


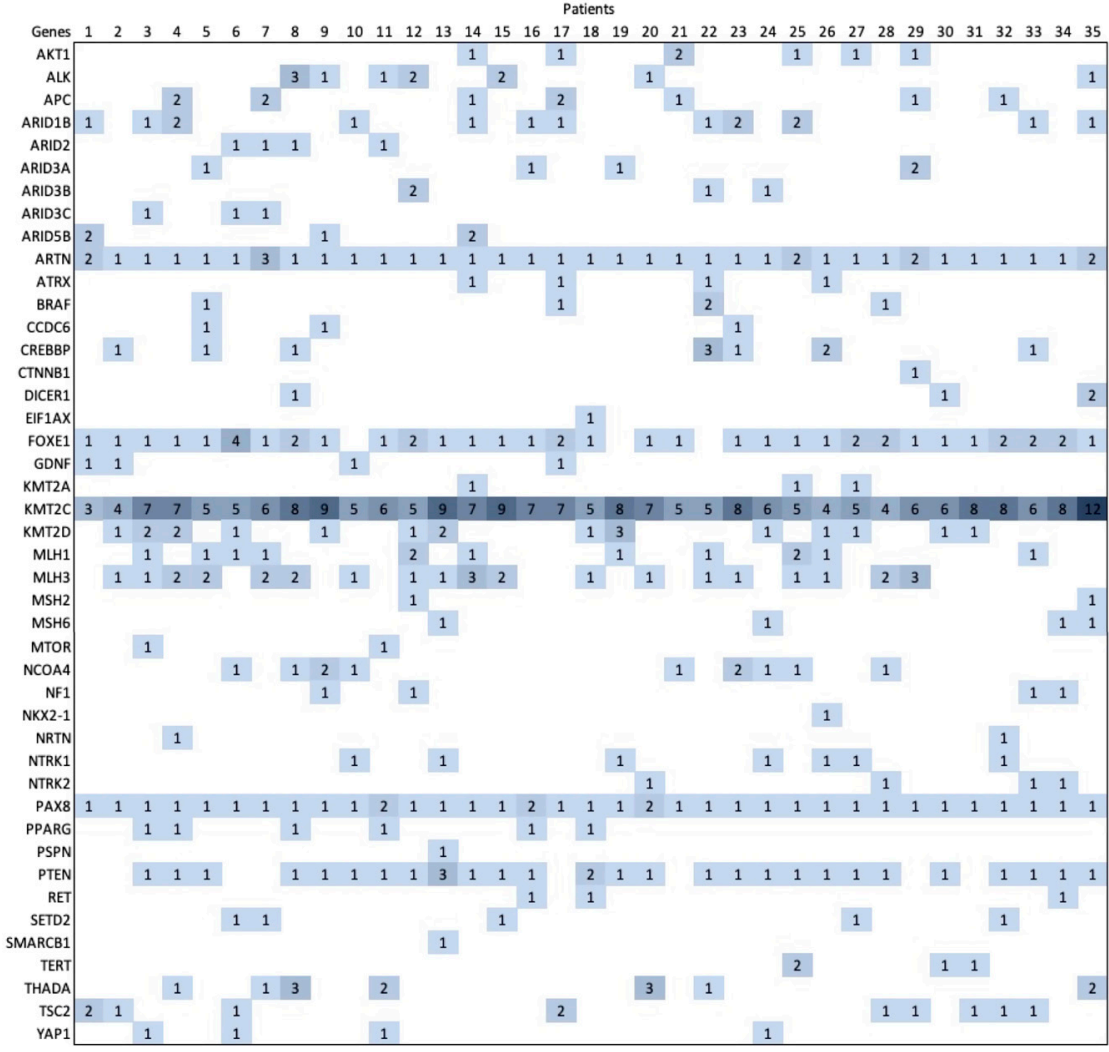

in exons and regulatory regions (5'UTRs) identified in the genome of $35 \mathrm{TD}$ patients were analyzed through a list of 44 driver genes directly related to the development of medullary, papillary, and follicular types of DTC (Santoro \& Carlomagno 2016) a high number of genetic alterations associated to the etiology of DTC (Fig. 2) (Brust \& Rubio unpublished observations). Nevertheless, a great number of these variants were those without information on their population frequency; thus, comparative and even functional studies are needed to clarify their real meaning.

\section{Alternative mechanisms of oncogenic activation}

\section{Somatic driver mutations}

Constitutive activation of MAPK is considered crucial for the initiation of PTC, mainly through mutations in the $B R A F$ and $R A S$ genes or gene fusions of tyrosine receptor
Figure 2

Genetic alterations in driver genes directly related with DTC subtypes (Santoro \& Carlomagno 2016) identified in TD patients. AKT1, AKT serine/ threonine kinase 1; ALK, ALK receptor tyrosine kinase; APC, APC regulator of WNT signaling pathway; ARID1B, AT-rich interaction domain 1B; ARID2, AT-rich interaction domain 2; ARID3A, AT-rich interaction domain 3A; ARID3B, AT-rich interaction domain 3B; ARID3C, AT-rich interaction domain 3C; ARID5B, AT-rich interaction domain 5B; ARTN, Artemin; ATRX, ATRX chromatin remodeler; BRAF, B-Raf proto-oncogene, serine/ threonine kinase; $C C D C 6$, coiled-coil domain containing 6; CREBBP, CREB binding protein; CTNNB1, catenin beta 1; DICER1, Dicer 1, ribonuclease III; EIF1AX, eukaryotic translation initiation factor $1 \mathrm{~A} X$ X-linked; FOXE1, forkhead box E1; GDNF, glial cell-derived neurotrophic factor; KMT2A, lysine methyltransferase $2 \mathrm{~A}$; KMT2C, lysine methyltransferase 2C; KMT2D, lysine methyltransferase 2D; MLH1, MutL homolog 1; MLH3, MutL homolog 3; MSH2, MutS homolog 2; MSH6, MutS homolog 6; MTOR, mechanistic target of rapamycin kinase; NCOA4, nuclear rceptor coactivator 4; NF1, neurofibromin 1; NKX2.1, NK2 homeobox 1; NRTN, neurturin; NTRK1, neurotrophic receptor tyrosine kinase 1; NTRK2, neurotrophic receptor tyrosine kinase 2; PAX8, paired box 8; PPARG, peroxisome proliferator activated receptor gamma; PSPN, persephin; PTEN, phosphatase and tensin homolog; RET, Ret proto-oncogene; SETD2, SET domain containing 2, histone lysine methyltransferase; SMARCB1, SWI/SNF related, matrix associated, actin dependent regulator of chromatin, subfamily $B$ member 1; TERT, telomerase reverse transcriptase; THADA, THADA armadillo repeat containing; TSC2, TSC complex subunit 2; YAP1, Yes1 associated transcriptional regulator. kinases such as RET/PTC, NTRK, and ALK. On the other hand, PI3K/AKT activation is critical for the development of follicular adenoma and progression to FTC due to mutations in RAS, PI3KCA, and AKT1 and by inactivating PTEN, which negatively regulates this pathway (Xing 2013, Zaballos \& Santisteban 2017). However, few studies have molecularly characterized the thyroid cancer of $\mathrm{CH}$ patients, and only BRAFV600E mutations were detected (Table 1).

\section{Chronic raised TSH}

Increased risk of neoplastic transformation in children with DHG and elevated TSH over a long period were proposed earlier (Medeiros-Neto \& Stanbury 1994). Up to now, only one study examined $\mathrm{CH}$ linked to TG gene mutations associated with DTC in seven patients with long-standing goiters, in a context of long-standing TSH stimulation and BRAFV600E somatic mutations (Hishinuma et al. 2005). (c) 2021 Society for Endocrinology Published by Bioscientifica Ltd. Printed in Great Britain 


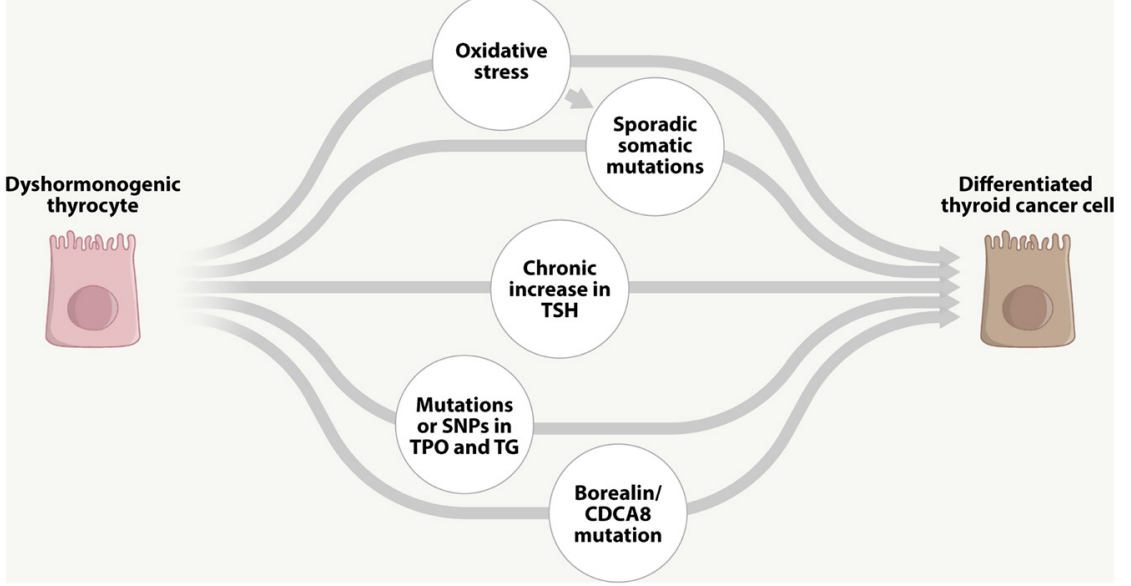

\section{Figure 3}

Hypothetical model of the process of carcinogesis of a dyshormonogenic thyrocyte. Borealin/CDCA8, cell division cycle associated 8 (Borealin/CDC8); SNP, single-nucleotide polymorphism; TG, thyroglobulin; TGO, thyroperoxidase; $\mathrm{TSH}$, thyroid-stimulating hormone.
The cooperation of BRAFV600E mutation and TSHR signaling activation has been investigated in mouse models (Lu et al. 2010). The genetic contribution of TSHR variants in TSH levels and cancer risk through GWAS metanalyses in 119,715 individuals identified 99 independent variants linked to TSH levels and 18 variants associated with DTC (Zhou et al. 2020). Therefore, the association between high TSH serum levels and DTC in patients with $\mathrm{CH}$ is not yet consensual and fully established, albeit, in a certain genetic context, it could be plausible.

\section{Oxidative stress}

$\mathrm{H}_{2} \mathrm{O}_{2}$ is required for thyroid hormone synthesis and may be involved in carcinogenesis via many mechanisms, including oxidative damage to DNA, gene expression, cell apoptosis, signaling, and proliferation (Carvalho \& Dupuy 2013, Ameziane-El-Hassani et al. 2016). At higher concentrations, $\mathrm{H}_{2} \mathrm{O}_{2}$ induces oxidative stress, DNA oxidation, and damage-causing mutagenic and neoplastic events due to the activation of proto-oncogenes or inactivation of tumor suppressors genes combined with its proliferative effects (Stone 2004). A hypothetical model of the process of carcinogenesis of a dyshormonogenic thyrocyte, that includes the oxidative stress, chronic increase of TSH, increased ROS production, and mutation/ polymorphisms of genes as Borealin/CDC8, TG, and TPO, is illustrated in Fig. 3.

Indeed, a functional interaction, at the plasma membrane, between DUOX and TPO regulates the extracellular $\mathrm{H}_{2} \mathrm{O}_{2}$ levels and may limit its diffusion into the cells as a protection from oxidative damage (Fortunato 2010). It is not known that if lack of a functional TPO could potentially be involved in neoplastic events in $\mathrm{CH}$ patients with TPO loss-of-function mutations (El Hassani 2019).
In human thyroid cells, NOX4 is overexpressed and positively regulated by TSH at transcriptional levels and is mainly expressed in intracellular compartments. NOX4 produces ROS in the perinuclear region of thyroid cells, probably exposing the nucleus to oxidative stress and inducing DNA damage (Weyemi 2010). The BRAFV600E mutation, the most frequent genomic alteration found in DTCs, upregulates NOX4 via the TGF-b1-SMAD3 pathway in thyroid cancer cells and downregulates NIS expression. It was suggested that NIS and other genes associated with thyroid differentiation might be silenced by a mechanism controlled by NOX4-derived ROS (Azouzi et al. 2017). The expression of NOX4 in $\mathrm{CH}$ patients with chronic elevated TSH has never been evaluated.

\section{Thyroid cancer diagnostic pitfalls in patients with congenital hypothyroidism with nodular goiter}

Adequate cytological diagnosis in nodules of patients with dyshormonogenesis might be demanding as a result of specific architectural and cytological appearances that may lead to an erroneous interpretation of the malignancy. The main findings are summarized in Table 2 (Matos et al. 1994, Mahajan et al. 2019). The cytological approach needs much refinement, encompassing the discernment of many conditions, such as hyperplastic nodule, post-radioiodine changes, follicular neoplasm, and non-invasive follicular thyroid neoplasm with papillary-like nuclear features (Matos et al. 1994, Mahajan et al. 2019). There may also be foci of papillary hyperplasia and mitotic activity, which could again lead to overdiagnosis of DTC. It is not rare for the cytological conclusion to be atypia of undetermined significance/follicular lesion of undetermined significance, 
Table 2 Cytological and anatomopathological features observed in dyshormonogenetic goiter (Fadda et al. 1999, Baloch \& LiVolsi 2006).

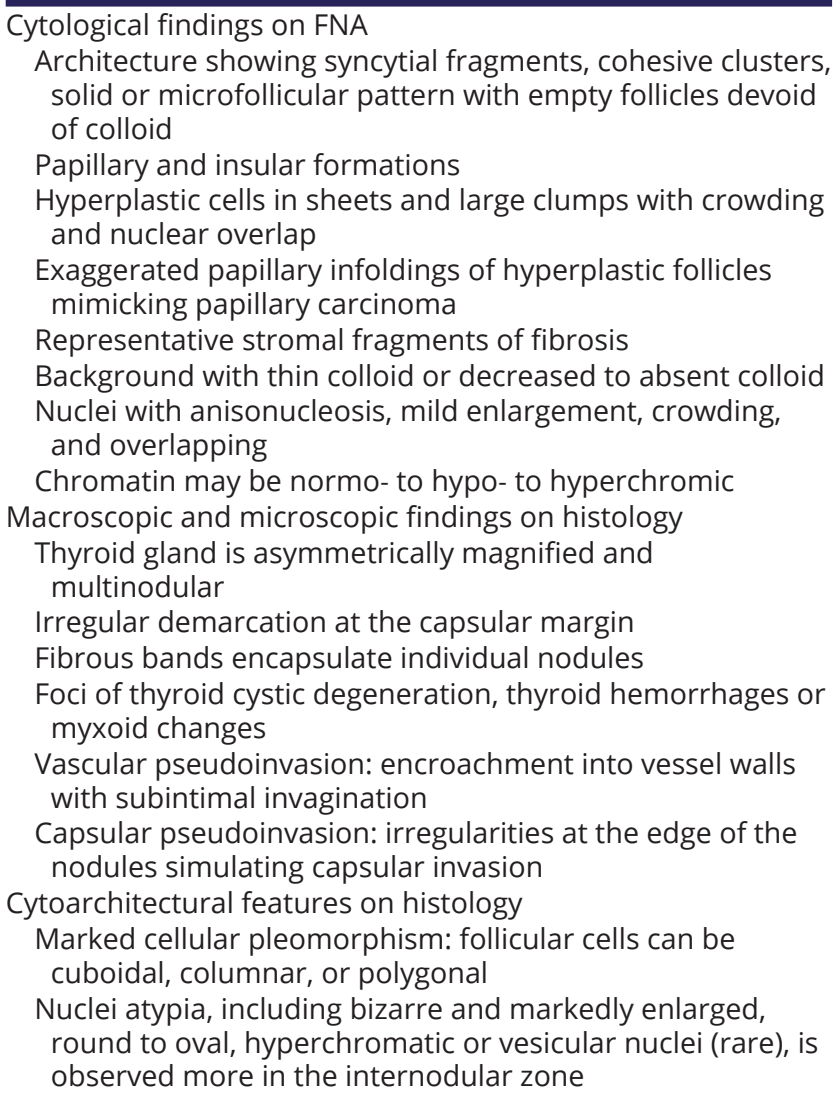

combined with focal cytological and architectural atypia (Matos et al. 1994, Mahajan et al. 2019). Hence, the histological examination must be largely scrupulous since lifelong TSH stimulation might be a powerful driver of many architectural changes and cellular pleomorphism (Table 2) (Ghossein et al. 1997, Fadda et al. 1999, Pedrinola et al. 2001, Deshpande \& Bobhate 2005, Drut \& Moreno 2009, Kallel et al. 2009). In contrast, features such as capsular or vessel invasion, papillary-like arrangement, nuclear pseudo inclusions or grooves drive the diagnosis of DTC (Ghossein et al. 1997, Fadda et al. 1999, Pedrinola et al. 2001, Deshpande \& Bobhate 2005, Drut \& Moreno 2009, Kallel et al. 2009). The nuclear changes noticed are most common in the inter-nodular areas rather than in the nodules themselves, and it is essential to highlight that the perception of analogous features in the epithelium of the thyroid follicles outside the nodules is a tremendous aid for proper judgment of interpretation (Camargo et al. 1998, Fadda et al. 1999, Baloch \& LiVolsi 2006, Braham et al. 2013). Follicular adenoma can be distinguished, and its capsule may appear focally disrupted; in this case, some observers advise that diagnosis of malignancy can only be made if the metastasis is documented (Rastogi \& LaFranchi 2010). Occasionally, the DTC diagnosis can be challenging and guaranteed only in some cases that present vascular invasion (much more critical than capsular invasion), extra-thyroid extension or lymph node metastasis (Cooper et al. 1981). If trabecular, solid, insular or cribriform growth patterns are observed, the differential diagnosis must cover an undifferentiated carcinoma, and awareness of the possible DH problem will be extremely helpful (Deshpande \& Bobhate 2005). It is a fact that these confounders' aspects are typically more expected in patients who have not been diagnosed early and who, secondary to a prolonged TSH boost effect, present a palpable goiter (Fadda et al. 1999).

Thepossiblepeculiarities in the therapy of thyroid cancer occurring in the context of congenital hypothyroidism are surgical difficulties in a tumor that are in ectopic or hyperplastic tissue. Nevertheless, the overall management in the therapy of thyroid cancer occurring in the context of congenital hypothyroidism does not have differences and or peculiarities/ particularities in relation to the treatment in pediatric thyroid cancer that does not have an association with congenital hypothyroidism (Francis et al. 2015).

\section{Conclusions}

The development of CDT combined with $\mathrm{CH}$ is a rare situation, with no well-established causal relationship. In association with dyshormonogenesis, as explained above, it has been suggested that one of the factors involved is the long exposure to elevated serum TSH levels, as well as stimulating factors or a lack of tumor-suppressor genes, type of mutation, patient's iodine intake, others genetic and environmental factors and the presence of congenital goiter. It is important to remember that these patients are under greater surveillance, do more ultrasound, and this can be a bias for the association between $\mathrm{CH}$ and CDT.

This review warns the possibility of the occurrence of DTC in this group of patients with $\mathrm{CH}$, and that it is advisable for a long-term follow-up by regular neck ultrasonographic imaging followed by fine-needle aspiration, if indicated, is recommended to avoid a delayed diagnosis of thyroid carcinoma in these cases. The mechanism that might lead to DTC in patients with $\mathrm{CH}$ still needs better elucidation. Elevated TSH, increased ROS production, and mutation/polymorphisms of genes as Borealin/CDC8, TG, and TPO have been associated with increased cancer risk or pro-tumoral cell behavior and might be potentially involved in this process. 
Finally, these associations highlighted in this review are not yet consensual and fully established. A better characterization of the genetic and epigenetic background of $\mathrm{CH}$ patients in the future will lead to a better mechanistic insight into how this condition might or not predispose to thyroid cancer.

\section{Declaration of interest}

The authors declare that there is no conflict of interest that could be perceived as prejudicing the impartiality of this review.

\section{Funding}

This work did not receive any specific grant from any funding agency in the public, commercial or not-for-profit sector.

\section{Acknowledgements}

The authors thank FAPESP 2014/24549-4, Sao Paulo State Research Foundation, and Coordenação de Aperfeiçoamento de Pessoal de Nível Superior - Brasil (CAPES) - Finance Code 001.

\section{References}

Abs R, Verhelst J, Schoofs E \& De Somer E 1991 Hyperfunctioning metastatic follicular thyroid carcinoma in Pendred's syndrome. Cancer 67 2191-2193. (https://doi.org/10.1002/1097-

0142(19910415)67:8<2191::aid-cncr2820670831>3.0.co;2-b)

Agretti P, Bagattini B, De Marco G, Di Cosmo C, Dionigi G, Vitti P \& Tonacchera M 2016 Papillary thyroid cancer in a patient with congenital goitrous hypothyroidism due to a novel deletion in NIS gene. Endocrine 54 256-258. (https://doi.org/10.1007/s12020-015-0790-8)

Alzahrani AS, Baitei EY, Zou M \& Shi Y 2006 Clinical case seminar: metastatic follicular thyroid carcinoma arising from congenital goiter as a result of a novel splice donor site mutation in the thyroglobulin gene. Journal of Clinical Endocrinology and Metabolism 91 740-746. (https://doi.org/10.1210/jc.2005-2302)

Ameziane-El-Hassani R, Schlumberger M \& Dupuy C 2016 NADPH oxidases: new actors in thyroid cancer? Nature Reviews: Endocrinology 12 485-494. (https://doi.org/10.1038/nrendo.2016.64)

Azouzi N, Cailloux J, Cazarin JM, Knauf JA, Cracchiolo J, Al Ghuzlan A, Hartl D, Polak M, Carré A, El Mzibri M, et al. 2017 NADPH oxidase NOX4 is a critical mediator of BRAFV600E-induced downregulation of the sodium/iodide symporter in papillary thyroid carcinomas. Antioxidants and Redox Signaling 26 864-877. (https://doi.org/10.1089/ ars.2015.6616)

Baloch ZW \& LiVolsi VA 2006 Cytologic and architectural mimics of papillary thyroid carcinoma. Diagnostic challenges in fine-needle aspiration and surgical pathology specimens. American Journal of Clinical Pathology 125 S135-S144. (https://doi.org/10.1309/ YY72M308WPEKL1YY)

Bann DV, Jin Q, Sheldon KE, Houser KR, Nguyen L, Warrick JI, Baker MJ, Broach JR, Gerhard GS \& Goldenberg D 2019 Genetic variants implicate dual oxidase- 2 in familial and sporadic nonmedullary thyroid cancer. Cancer Research 79 5490-5499. (https://doi. org/10.1158/0008-5472.CAN-19-0721)

Bashir EA, Ahmed S, Murtaza B, Abbasi MH, Shah SS, Tamimy MS \& Awan AS 2004 Follicular carcinoma thyroid in pendred syndrome.
Journal of the College of Physicians and Surgeons Pakistan 14 679-680. (https://doi.org/11.2004/JCPSP.679680)

Boelaert K 2009 The association between serum TSH concentration and thyroid cancer. Endocrine-Related Cancer 16 1065-1072. (https://doi. org/10.1677/ERC-09-0150)

Bougacha-Elleuch N, Charfi N, Miled N, Bouhajja H, Belguith N, Mnif M, Jaurge P, Chikhrouhou N, Ayadi H, Hachicha M, et al. 2015 Segregation of S292F TPO gene mutation in three large tunisian families with thyroid dyshormonogenesis: evidence of a founder effect. European Journal of Pediatrics 174 1491-1501. (https://doi.org/10.1007/s00431015-2550-4)

Braham E, Ben Rejeb H, Marghli A, Kilani T \& El Mezni F 2013 A rare and particular form of goiter to recognize. Annals of Translational Medicine 1 21. (https://doi.org/10.3978/j.issn.2305-5839.2013.01.10)

Camargo RYA, Gross JL, Silveiro SP, Knobel M \& Medeiros-Neto G 1998 Pathological findings in dyshormonogenetic goiter with defective iodide transport. Endocrine Pathology 9 225-233. (https://doi. org/10.1007/BF02739962)

Camargo R, Limbert E, Gillam M, Henriques MM, Fernandes C, Catarino AL, Soares J, Alves VA, Kopp P \& Medeiros-Neto G 2001 Aggressive metastatic follicular thyroid carcinoma with anaplastic transformation arising from a long-standing goiter in a patient with Pendred's syndrome. Thyroid 11 981-988. (https://doi. org/10.1089/105072501753211073)

Camargo RY, Kanamura CT, Friguglietti CU, Nogueira CR, Iorcansky S, Tincani AJ, Bezerra AK, Brust E, Koyama FC, Camargo AA, et al. 2018 Histopathological characterization and whole exome sequencing of ectopic thyroid: fetal architecture in a functional ectopic gland from adult patient. International Journal of Endocrinology $\mathbf{2 0 1 8} 4682876$. (https://doi.org/10.1155/2018/4682876)

Cantara S, Capuano S, Formichi C, Pisu M, Capezzone M \& Pacini F 2010 Lack of germline A339V mutation in thyroid transcription factor-1 (TITF-1/NKX2.1) gene in familial papillary thyroid cancer. Thyroid Research 3 4. (https://doi.org/10.1186/1756-6614-3-4)

Carré A, Hamza RT, Kariyawasam D, Guillot L, Teissier R, Tron E, Castanet M, Dupuy C, El Kholy M \& Polak M 2014 A novel FOXE1 mutation (R73S) in Bamforth-Lazarus syndrome causing increased thyroidal gene expression. Thyroid 24 649-654. (https://doi. org/10.1089/thy.2013.0417)

Carré A, Stoupa A, Kariyawasam D, Gueriouz M, Ramond C, Monus T, Léger J, Gaujoux S, Sebag F, Glaser N, et al. 2017 Mutations in BOREALIN cause thyroid dysgenesis. Human Molecular Genetics 26 599-610. (https://doi.org/10.1093/hmg/ddw419)

Carvalho DP \& Dupuy C 2013 Role of the NADPH oxidases DUOX and NOX4 in thyroid oxidative stress. European Thyroid Journal 2 160-167. (https://doi.org/10.1159/000354745)

Castanet M, Leenhardt L, Léger J, Simon-Carré A, Lyonnet S, Pelet A, Czernichow P \& Polak M 2005 Thyroid hemiagenesis is a rare variant of thyroid dysgenesis with a familial component but without Pax8 mutations in a cohort of 22 cases. Pediatric Research 57 908-913. (https://doi.org/10.1203/01.PDR.0000161409.04177.36)

Castro MR, Espiritu RP, Bahn RS, Henry MR, Gharib H, Caraballo PJ \& Morris JC 2011 Predictors of malignancy in patients with cytologically suspicious thyroid nodules. Thyroid 21 1191-1198. (https://doi. org/10.1089/thy.2011.0146)

Cerqueira TLO, Ramos YR, Strappa GB, Jesus MS, Santos JG, Sousa C, Carvalho G, Fernandes V, Boa-Sorte N, Amorim T, et al. 2018 Mutation screening in the genes PAX-8, NKX2-5, TSH-R, HES-1 in cohort of 63 Brazilian children with thyroid dysgenesis. Archives of Endocrinology and Metabolism 62 466-471. (https://doi.org/10.20945/23593997000000065)

Chen XQ, Shi RH, Huang JT \& Zhao YF 2013 Follicular variant of papillary carcinoma arising from lingual thyroid with orthotopic hypoplasia of thyroid lobes. Journal of Oral and Maxillofacial Surgery 71 644-648. (https://doi.org/10.1016/j.joms.2012.06.190)
(C) 2021 Society for Endocrinology Published by Bioscientifica Ltd. Printed in Great Britain 
Chertok Shacham E, Ishay A, Irit E, Pohlenz J \& Tenenbaum-Rakover Y 2012 Minimally invasive follicular thyroid carcinoma developed in dyshormonogenetic multinodular goiter due to thyroid peroxidase gene mutation. Thyroid 22 542-546. (https://doi.org/10.1089/thy.2011.0478)

Cipollini M, Pastor S, Gemignani F, Castell J, Garritano S, Bonotti A, Biarnés J, Figlioli G, Romei C, Marcos R, et al. 2013 TPO genetic variants and risk of differentiated thyroid carcinoma in two European populations. International Journal of Cancer 133 2843-2851. (https:// doi.org/10.1002/ijc.28317)

Cooper DS, Axelrod L, DeGroot LJ, Vickery AL \& Maloof F 1981 Congenital goiter and the development of metastatic follicular carcinoma with evidence for a leak of nonhormonal iodide: clinical, pathological, kinetic, and biochemical studies and a review of the literature. Journal of Clinical Endocrinology and Metabolism 52 294-306. (https://doi.org/10.1210/jcem-52-2-294)

Crooks J, Greig W \& Branwood AW 1963 Dyshormonogenesis and carcinoma of the thyroid gland. Scottish Medical Journal 8 303-307. (https://doi.org/10.1177/003693306300800802)

Deshpande AH \& Bobhate SK 2005 Cytological features of dyshormonogenetic goiter: case report and review of the literature. Diagnostic Cytopathology 33 252-254. (https://doi.org/10.1002/ dc.20348)

Diaz-Arias AA, Bickel JT, Loy TS, Croll GH, Puckett CL \& Havey AD 1992 Follicular carcinoma with clear cell change arising in lingual thyroid. Oral Surgery, Oral Medicine, and Oral Pathology 74 206-211. (https://doi. org/10.1016/0030-4220(92)90384-3)

Drut R \& Moreno A 2009 Papillary carcinoma of the thyroid developed in congenital dyshormonogenetic hypothyroidism without goiter: diagnosis by FNAB. Diagnostic Cytopathology 37 707-709. (https://doi. org/10.1002/dc.20916)

El Hassani RA, Buffet C, Leboulleux S \& Dupuy C 2019 Oxidative stress in thyroid carcinomas: biological and clinical significance. EndocrineRelated Cancer 26 R131-R143. (https://doi.org/10.1530/ERC-18-0476)

Erden ES, Babayigit C, Davran R, Akin M, Karazincir S, Isaogullari N, Demirkose M \& Genc S 2013 Papillary thyroid carcinoma with lung metastasis arising from dyshormonogenetic goiter: a case report. Case Reports in Medicine 2013 813167. (https://doi.org/10.1155/2013/813167)

Fadda G, Baloch ZW \& LiVolsi VA 1999 Dyshormonogenetic goiter pathology: a review. International Journal of Surgical Pathology 7 125-131. (https://doi.org/10.1177/106689699900700301)

Fernández LP, López-Márquez A \& Santisteban P 2015 Thyroid transcription factors in development, differentiation and disease. Nature Reviews: Endocrinology 11 29-42. (https://doi.org/10.1038/ nrendo.2014.186)

Fiore E, Rago T, Provenzale MA, Scutari M, Ugolini C, Basolo F, Di Coscio G, Miccoli P, Grasso L, Pinchera A, et al. 2010 L-thyroxinetreated patients with nodular goiter have lower serum TSH and lower frequency of papillary thyroid cancer: results of a cross-sectional study on 27914 patients. Endocrine-Related Cancer 17 231-239. (https://doi. org/10.1677/ERC-09-0251)

Fortunato RS, Lima de Souza EC, Ameziane-el Hassani R, Boufraqech M, Weyemi U, Talbot M, Lagente-Chevallier O, de Carvalho DP, Bidart JM, Schlumberger M, et al. 2010 Functional consequences of dual oxidasethyroperoxidase interaction at the plasma membrane. Journal of Clinical Endocrinology and Metabolism 95 5403-5411. (https://doi. org/10.1210/jc.2010-1085)

Francis GL, Waguespack SG, Bauer AJ, Angelos P, Benvenga S, Cerutti JM, Dinauer CA, Hamilton J, Hay ID, Luster M, et al. 2015 Management guidelines for children with thyroid nodules and differentiated thyroid cancer. Thyroid 25 716-759. (https://doi.org/10.1089/ thy.2014.0460)

Ghossein RA, Rosai J \& Heffess C 1997 Dyshormonogenetic goiter: a clinicopathologic study of 56 cases. Endocrine Pathology 8 283-292. (https://doi.org/10.1007/BF02739930)

Grasberger H \& Refetoff S 2011 Genetic causes of congenital hypothyroidism due to dyshormonogenesis. Current Opinion in
Pediatrics 23 421-428. (https://doi.org/10.1097/ MOP.0b013e32834726a4)

Gudmundsson J, Sulem P, Gudbjartsson DF, Jonasson JG, Sigurdsson A, Bergthorsson JT, He H, Blondal T, Geller F, Jakobsdottir M, et al. 2009 Common variants on $9 \mathrm{q} 22.33$ and $14 \mathrm{q} 13.3$ predispose to thyroid cancer in European populations. Nature Genetics 41 460-464. (https:// doi.org/10.1038/ng.339)

Gupta A, Ly S, Castroneves LA, Frates MC, Benson CB, Feldman HA, Wassner AJ, Smith JR, Marqusee E, Alexander EK, et al. 2013 A standardized assessment of thyroid nodules in children confirms higher cancer prevalence than in adults. Journal of Clinical Endocrinology and Metabolism 98 3238-3245. (https://doi.org/10.1210/ jc.2013-1796)

Hayek A, Maloof F \& Crawford JD 1973 Thyrotropin behavior in thyroid disorders of childhood. Pediatric Research 7 28-38. (https://doi. org/10.1203/00006450-197301000-00005)

Hishinuma A, Fukata S, Kakudo K, Murata Y \& Ieiri T 2005 High incidence of thyroid cancer in long-standing goiters with thyroglobulin mutations. Thyroid 15 1079-1084. (https://doi.org/10.1089/ thy.2005.15.1079)

Huang SM, Chen HD, Wen TY \& Kun MS 2002 Right thyroid hemiagenesis associated with papillary thyroid cancer and an ectopic prelaryngeal thyroid: a case report. Journal of the Formosan Medical Association 101 368-371.

Huang NS, Wei WJ, Qu N, Wang YL, Wang Y \& Ji QH 2019 Lingual ectopic papillary thyroid carcinoma: two case reports and review of the literature. Oral Oncology 88 186-189. (https://doi.org/10.1016/j. oraloncology.2018.11.019)

Huel C, Guibourdenche J, Vuillard E, Ouahba J, Piketty M, Oury JF \& Luton D 2009 Use of ultrasound to distinguish between fetal hyperthyroidism and hypothyroidism on discovery of a goiter. Ultrasound in Obstetrics and Gynecology 33 412-420. (https://doi. org/10.1002/uog.6315)

Illum P 1978 Thyroid carcinoma in pendred's syndrome. Journal of Laryngology and Otology 92 435-439. (https://doi.org/10.1017/ s0022215100085571)

Kallel R, Mnif Hachicha L, Mnif M, Hammami B, Ayadi L, Bahri I, Ghorbel A, Abid M, Makni S \& Boudawara T 2009 Cancer papillaire sur goitre dyshormonogénétique. Annales d'Endocrinologie 70 485-488. (https://doi.org/10.1016/j.ando.2009.08.001)

Kennedy TL \& Riefkohl WL 2007 Lingual thyroid carcinoma with nodal metastasis. Laryngoscope 117 1969-1973. (https://doi.org/10.1097/ MLG.0b013e31812e0160)

Kim S-H, Jung J-Y, Shin S-J, Park S-Y, Lee S-H, Kim Y-M, Rhee Y-M, Hong SW, Cha B-S, Ahn C-W, et al. 2004 A case of follicular thyroid carcinoma developed in pendred syndrome. Endocrinology and Metabolism 19 411-418.

Kim KW, Park YJ, Kim EH, Park SY, Park DJ, Ahn SH, Park DJ, Jang HC \& Cho BY 2011 Elevated risk of papillary thyroid cancer in korean patients with hashimoto's thyroiditis. Head and Neck 33 691-695. (https://doi.org/10.1002/hed.21518)

Klubo-Gwiezdzinska J, Manes RP, Chia SH, Burman KD, Stathatos NA, Deeb ZE \& Wartofsky L 2011 Ectopic cervical thyroid carcinoma review of the literature with illustrative case series. Journal of Clinical Endocrinology and Metabolism 96 2684-2691. (https://doi.org/10.1210/ jc.2011-0611)

Kuleshov MV, Jones MR, Rouillard AD, Fernandez NF, Duan Q, Wang Z, Koplev S, Jenkins SL, Jagodnik KM, Lachmann A, et al. 2016 Enrichr: a comprehensive gene set enrichment analysis web server 2016 update. Nucleic Acids Research 44 W90-W97. (https://doi.org/10.1093/nar/ gkw377)

Landa I, Ruiz-Llorente S, Montero-Conde C, Inglada-Pérez L, Schiavi F, Leskelä S, Pita G, Milne R, Maravall J, Ramos I, et al. 2009 The variant rs1867277 in FOXE1 gene confers thyroid cancer susceptibility through the recruitment of USF1/USF2 transcription factors. PLoS Genetics 5 e1000637. (https://doi.org/10.1371/journal.pgen.1000637) https://erc bioscientifica com

https://doi.org/10.1530/ERC-21-0159 (c) 2021 Society for Endocrinology Published by Bioscientifica Ltd. Printed in Great Britain 
Lu C, Zhao L, Ying H, Willingham MC \& Cheng SY 2010 Growth activation alone is not sufficient to cause metastatic thyroid cancer in a mouse model of follicular thyroid carcinoma. Endocrinology 151 1929-1939. (https://doi.org/10.1210/en.2009-1017)

Mahajan S, Agarwal S, Sharma MC, Ray R, Nakra T, Kandasamy D \& Chumber S 2019 Cytological features of dyshormonogenetic goitre: a diagnostic pitfall. Cytopathology 30 125-127. (https://doi.org/10.1111/ cyt.12650)

Maiorana R, Carta A, Floriddia G, Leonardi D, Buscema M, Sava L, Calaciura F \& Vigneri R 2003 Thyroid hemiagenesis: prevalence in normal children and effect on thyroid function. Journal of Clinical Endocrinology and Metabolism 88 1534-1536. (https://doi.org/10.1210/ jc.2002-021574)

Matos PS, Bisi H \& Medeiros-Neto G 1994 Dyshormonogenetic goiter: a morphological and immunohistochemical study. Endocrine Pathology 5 49-58. (https://doi.org/10.1007/BF02921370)

McGirr EM, Clement WE, Currie AR \& Kennedy JS 1959 Impaired dehalogenase activity as a cause of goitre with malignant changes. Scottish Medical Journal 4 232-241. (https://doi. org/10.1177/003693305900400503)

McHenry CR, Walfish PG, Rosen IB, Lawrence AM \& Paloyan E 1995 Congenital thyroid hemiagenesis. American Surgeon 61 634-638.

Medeiros-Neto GA \& Oliveira NRC 1970 Follicular adenocarcinoma of thyroid associated with congenital hyperplastic goiter. Acta Endocrinology 1 73-89.

Medeiros-Neto G \& Stanbury JB 1994 The iodotyrosine deiodinase defect. In Inherited Disorders of the Thyroid System. Eds G Medeiros-Neto \& JB Stanbury. Boca Raton: CRC Press, pp. 139-159.

Medeiros-Neto G, Gil-Da-Costa MJ, Santos CL, Medina AM, Silva JC, Tsou RM \& Sobrinho-Simões M 1998 Metastatic thyroid carcinoma arising from congenital goiter due to mutation in the thyroperoxidase gene. Journal of Clinical Endocrinology and Metabolism 83 4162-4166. (https://doi.org/10.1210/jcem.83.11.5264)

Mikosch P, Gallowitsch HJ, Kresnik E, Molnar M, Gomez I \& Lind P 1999 Thyroid hemiagenesis in an endemic goiter area diagnosed by ultrasonography: report of sixteen patients. Thyroid 9 1075-1084. (https://doi.org/10.1089/thy.1999.9.1075)

Mogi C, Shinomiya H, Fujii N, Tsuruta T, Morita N, Furukawa T, Teshima M, Kanzawa M, Hirokawa M, Otsuki N, et al. 2018 Transoral videolaryngoscopic surgery for papillary carcinoma arising in lingual thyroid. Auris, Nasus, Larynx 45 1127-1129. (https://doi.org/10.1016/j. anl.2018.04.003)

Muzza M \& Fugazzola L 2017 Disorders of $\mathrm{H} 2 \mathrm{O} 2$ generation. Best Practice and Research: Clinical Endocrinology and Metabolism 31 225-240. (https://doi.org/10.1016/j.beem.2017.04.006)

Nascimento AC, Guedes DR, Santos CS, Knobel M, Rubio IGS \& Medeiros-Neto G 2003 Thyroperoxidase gene mutations in congenital goitrous hypothyroidism with total and partial iodide organification defect. Thyroid 13 1145-1151. (https://doi. org/10.1089/10507250360731550)

Ngan ESW, Lang BHH, Liu T, Shum CKY, So MT, Lau DKC, Leon TYY, Cherny SS, Tsai SY, Lo CY, et al. 2009 A germline mutation (A339V) in thyroid transcription factor-1 (TITF-1/NKX2.1) in patients with multinodular goiter and papillary thyroid carcinoma. Journal of the National Cancer Institute 101 162-175. (https://doi.org/10.1093/jnci/ djn471)

Nicola JP, Nazar M, Serrano-Nascimento C, Goulart-Silva F, Sobrero G, Testa G, Nunes MT, Muñoz L, Miras M \& Masini-Repiso AM 2011 Iodide transport defect: functional characterization of a novel mutation in the $\mathrm{Na}^{+} / \mathrm{I}^{-}$symporter $5^{\prime}$-untranslated region in a patient with congenital hypothyroidism. Journal of Clinical Endocrinology and Metabolism 96 E1100-E1107. (https://doi.org/10.1210/jc.2011-0349)

Niedziela M 2006 Pathogenesis, diagnosis and management of thyroid nodules in children. Endocrine-Related Cancer 13 427-453. (https://doi. org/10.1677/erc.1.00882)
Nilsson M \& Fagman H 2017 Development of the thyroid gland. Development 144 2123-2140. (https://doi.org/10.1242/dev.145615)

Oguz A, Gul K, Inancli SS, Korukluoglu B, Ersoy R \& Cakir B 2009 Case Report: Papillary thyroid carcinoma in a patient with pendred syndrome. BioScientifica 20312.

Ozlük A, Yildirim E, Oral S, Celen O \& Berberoğlu U 1998 Carcinomas of the thyroid and breast associated with Pendred's syndrome: report of a case. Surgery Today 28 673-674. (https://doi.org/10.1007/ s005950050207)

Paulson VA, Rudzinski ER \& Hawkins DS 2019 Thyroid cancer in the pediatric population. Genes 10 723. (https://doi.org/10.3390/genes10090723)

Pedrinola F, Rubio I, Santos CL \& Medeiros-Neto G 2001 Overexpression of epidermal growth factor and epidermal growth factor-receptor mRNAs in dyshormonogenetic goiters. Thyroid 11 15-20. (https://doi. org/10.1089/10507250150500612)

Pérez JS, Muñoz M, Naval L, Blasco A \& Diaz FJ 2003 Papillary carcinoma arising in lingual thyroid. Journal of Cranio-Maxillo-Facial Surgery 31 179-182. (https://doi.org/10.1016/s1010-5182(03)00032-5)

Pessôa-Pereira D, Medeiros MFDS, Lima VMS, Silva JCD, Cerqueira TLO, Silva ICD, Fonseca LE, Sampaio LJL, Lima CRA \& Ramos HE 2019 Association between BRAF (V600E) mutation and clinicopathological features of papillary thyroid carcinoma: a Brazilian single-centre case series. Archives of Endocrinology and Metabolism 63 97-106. (https://doi. org/10.20945/2359-3997000000120)

Pizzini AM, Papi G, Corrado S, Carani C \& Roti E 2005 Thyroid hemiagenesis and incidentally discovered papillary thyroid cancer: case report and review of the literature. Journal of Endocrinological Investigation 28 66-71. (https://doi.org/10.1007/BF03345532)

Potter EB \& Morris WR 1935 Carcinoma of the thyroid gland. American Journal of Surgery 27 546-550. (https://doi.org/10.1016/S00029610(35)91043-1)

Raef H, Al-Rijjal R, Al-Shehri S, Zou M, Al-Mana H, Baitei EY, Parhar RS, Al-Mohanna FA \& Shi Y 2010 Biallelic p.R2223H mutation in the thyroglobulin gene causes thyroglobulin retention and severe hypothyroidism with subsequent development of thyroid carcinoma. Journal of Clinical Endocrinology and Metabolism 95 1000-1006. (https:// doi.org/10.1210/jc.2009-1823)

Ramos HE, Nesi-França S \& Maciel RM 2008 New aspects of genetics and molecular mechanisms on thyroid morphogenesis for the understading of thyroid dysgenesia. Arquivos Brasileiros de Endocrinologia e Metabologia 52 1403-1415. (https://doi.org/10.1590/ s0004-27302008000900003)

Rastogi MV \& LaFranchi SH 2010 Congenital hypothyroidism. Orphanet Journal of Rare Diseases 5 17. (https://doi.org/10.1186/1750-1172-5-17)

Rickles JA 1947 Carcinoma of the thyroid gland in children. American Journal of Surgery $\mathbf{7 4}$ 8-13. (https://doi.org/10.1016/00029610(47)90086- $\mathrm{x})$

Ris-Stalpers C \& Bikker H 2010 Genetics and phenomics of hypothyroidism and goiter due to TPO mutations. Molecular and Cellular Endocrinology 322 38-43. (https://doi.org/10.1016/j. mce.2010.02.008)

Roberts KD 1957 Thyroid carcinoma in childhood in Great Britain. Archives of Disease in Childhood 32 58-60. (https://doi.org/10.1136/ adc.32.161.58)

Rose J, Wertheim BC \& Guerrero MA 2012 Radiation treatment of patients with primary pediatric malignancies: risk of developing thyroid cancer as a secondary malignancy. American Journal of Surgery 204 881-886. (https://doi.org/10.1016/j.amjsurg.2012.07.030)

Rubio IGS \& Medeiros-Neto G 2009 Mutations of the thyroglobulin gene and its relevance to thyroid disorders. Current Opinion in Endocrinology, Diabetes, and Obesity 16 373-378. (https://doi.org/10.1097/ MED.0b013e32832ff218)

Sakurai K, Hata M, Hishinuma A, Ushijima R, Okada A, Taeda Y, Arihara Z, Fukazawa H \& Takahashi K 2013 Papillary thyroid carcinoma in one of identical twin patients with Pendred syndrome. (c) 2021 Society for Endocrinology Published by Bioscientifica Ltd. Printed in Great Britain 
Endocrine Journal 60 805-811. (https://doi.org/10.1507/endocrj.EJ120396)

Santoro M \& Carlomagno F 2016 Pathogenesis of thyroid carcinoma. In Thyroid Diseases. Endocrinology. Eds P Vitti \& L Hegedus. Cham: Springer. (https://doi.org/10.1007/978-3-319-29195-6_20-1)

Sevinç AI, Unek T, Canda AE, Guray M, Kocdor MA, Saydam S \& Harmancioglu O 2010 Papillary carcinoma arising in subhyoid ectopic thyroid gland with no orthotopic thyroid tissue. American Journal of Surgery 200 e17-e18. (https://doi.org/10.1016/j.amjsurg.2009.06.032)

Şıklar Z, Berberoğlu M, Yağmurlu A, Hacıhamdioğlu B, Savaş Erdeve S, Fitöz S, Kır M \& Öçal G 2012 Synchronous occurrence of papillary carcinoma in the thyroid gland and thyroglossal duct in an adolescent with congenital hypothyroidism. Journal of Clinical Research in Pediatric Endocrinology 4 30-33. (https://doi.org/10.4274/jcrpe.477)

Spitzweg C \& Morris JC 2010 Genetics and phenomics of hypothyroidism and goiter due to NIS mutations. Molecular and Cellular Endocrinology 322 56-63. (https://doi.org/10.1016/j.mce.2010.02.007)

Stanbury JB \& Vickery AL 1962 Physiological and pathological correlations in familial goitrous cretinism. Indian Journal of Pathology and Bacteriology 5 1-9.

Stone JR 2004 An assessment of proposed mechanisms for sensing hydrogen peroxide in mammalian systems. Archives of Biochemistry and Biophysics 422 119-124. (https://doi.org/10.1016/j.abb.2003.12.029)

Thieme ET 1957 A report of the occurrence of deafmutism and goiter in four of six siblings of a North American family. Annals of Surgery 146 941-948. (https://doi.org/10.1097/00000658-195712000-00008)

Tian L, Jiao Y, Liu M, Li M \& Yao H 2014 Ectopic thyroid papillary carcinoma of nasopharynx associated with adenoid hypertrophy: an unusual presentation. Head and Face Medicine 10 40. (https://doi. org/10.1186/1746-160X-10-40)

Tong GX, Chang Q, Hamele-Bena D, Carew J, Hoffman RS, Nikiforova MN \& Nikiforov YE 2016 Targeted next-generation sequencing analysis of a pendred syndrome-associated thyroid carcinoma. Endocrine Pathology 27 70-75. (https://doi.org/10.1007/s12022-015-9413-4)

Turcotte LM, Liu Q, Yasui Y, Arnold MA, Hammond S, Howell RM, Smith SA, Weathers RE, Henderson TO, Gibson TM, et al. 2017 Temporal trends in treatment and subsequent neoplasm risk Among 5-year survivors of childhood cancer, 1970-2015. JAMA 317 814-824. (https://doi.org/10.1001/jama.2017.0693)

van Trotsenburg P, Stoupa A, Léger J, Rohrer T, Peters C, Fugazzola L, Cassio A, Heinrichs C, Beauloye V, Pohlenz J, et al. 2021 Congenital hypothyroidism: a 2020-2021 consensus guidelines update-an endoEuropean reference network initiative endorsed by the European Society for Pediatric Endocrinology and the European Society for Endocrinology. Thyroid 31 387-419. (https://doi.org/10.1089/ thy.2020.0333)

Villani A, Greer M-LC, Kalish JM, Nakagawara A, Nathanson KL, Pajtler KW, Pfister SM, Walsh MF, Wasserman JD, Zelley K, et al. 2017
Recommendations for cancer surveillance in individuals with RASopathies and other rare genetic conditions with increased cancer risk. Clinical Cancer Research 23 e83-e90. (https://doi.org/10.1158/10780432.CCR-17-0631)

Wang J, Gao L \& Song C 2014 Thyroid hemiagenesis associated with medullary or papillary carcinoma: report of cases. Head and Neck $\mathbf{3 6}$ E106-E111. (https://doi.org/10.1002/hed.23501)

Wémeau JL \& Kopp P 2017 Pendred syndrome. Best Practice and Research: Clinical Endocrinology and Metabolism 31 213-224. (https://doi. org/10.1016/j.beem.2017.04.011)

Weyemi U, Caillou B, Talbot M, Ameziane-El-Hassani R, Lacroix L, LagentChevallier O, Al Ghuzlan A, Roos D, Bidart JM, Virion A, et al. 2010 Intracellular expression of reactive oxygen species-generating NADPH oxidase NOX4 in normal and cancer thyroid tissues. Endocrine-Related Cancer 17 27-37. (https://doi.org/10.1677/ERC-09-0175)

Wu YH, Wein RO \& Carter B 2010 Thyroid hemiagenesis with multinodular goiter: a case presentation and review of literature. Laryngoscope 120 S191. (https://doi.org/10.1002/lary.21655)

Wu YH, Wein RO \& Carter B 2012 Thyroid hemiagenesis: a case series and review of the literature. American Journal of Otolaryngology 33 299-302. (https://doi.org/10.1016/j.amjoto.2011.08.007)

Xing M 2013 Molecular pathogenesis and mechanisms of thyroid cancer 2013. Nature Reviews: Cancer 13 184-199. (https://doi.org/10.1038/ nrc3431)

Yashiro T, Ito K, Akiba M, Kanaji Y, Obara T, Fujimoto Y, Hirayama A \& Nakajima H 1987 Papillary carcinoma of the thyroid arising from dyshormonogenetic goiter. Endocrinologia Japonica 34 955-964. (https://doi.org/10.1507/endocrj1954.34.955)

Yoon JH, Hong AR, Kim HK \& Kang HC 2020 Anaplastic thyroid cancer arising from dyshormonogenetic goiter: c.3070T $>\mathrm{C}$ and Novel c.7070T $>$ C mutation in the thyroglobulin gene. Thyroid 30 1676-1680. (https://doi.org/10.1089/thy.2020.0248)

Zaballos MA \& Santisteban P 2017 Key signaling pathways in thyroid cancer. Journal of Endocrinology 235 R43-R61. (https://doi.org/10.1530/ JOE-17-0266)

Zhou W, Brumpton B, Kabil O, Gudmundsson J, Thorleifsson G, Weinstock J, Zawistowski M, Nielsen JB, Chaker L, Medici M, et al. 2020 GWAS of thyroid stimulating hormone highlights pleiotropic effects and inverse association with thyroid cancer. Nature Communications 11 3981. (https://doi.org/10.1038/s41467-020-17718-z)

Zhu H, Peng YG, Ma SG \& Liu H 2015 TPO gene mutations associated with thyroid carcinoma: case report and literature review. Cancer Biomarkers 15 909-913. (https://doi.org/10.3233/CBM-150522)

Zirilli G, Salzano G, Corica D, Pajno GB, Mignosa C, Pepe G, De Luca F \& Crisafulli G 2019 Thyrotropin serum levels and coexistence with Hashimoto's thyroiditis as predictors of malignancy in children with thyroid nodules. Italian Journal of Pediatrics $\mathbf{4 5}$ 96. (https://doi. org/10.1186/s13052-019-0693-z)

Received in final form 12 May 2021

Accepted 16 June 2021

Accepted Manuscript published online 17 June 2021
C) 2021 Society for Endocrinology Published by Bioscientifica Ltd. Printed in Great Britain 